\title{
Enterococcus villorum sp. nov., an enteroadherent bacterium associated with diarrhoea in piglets
}

\author{
M. Vancanneyt, ${ }^{1}$ C. Snauwaert, ${ }^{1}$ I. Cleenwerck, ${ }^{1}$ M. Baele, ${ }^{3}$ \\ P. Descheemaeker, ${ }^{4} \dagger$ H. Goossens, ${ }^{4}$ B. Pot, ${ }^{1} \ddagger$ P. Vandamme, ${ }^{2}$ J. Swings, ${ }^{1,2}$ \\ F. Haesebrouck ${ }^{3}$ and L. A. Devriese ${ }^{3}$
}

Author for correspondence: M. Vancanneyt. Tel: +329 2645115. Fax: +3292645092.

e-mail: Marc.Vancanneyt@rug.ac.be
1,2,3 BCCM/LMG Bacteria Collection ${ }^{1}$, Laboratory of Microbiology, Faculty of Sciences ${ }^{2}$ and Laboratory of Bacteriology, Faculty of Veterinary Medicine ${ }^{3}$, University of Gent, Gent, Belgium
${ }^{4}$ Department of Medical Microbiology, University Hospital, UIA, Antwerp, Belgium

\begin{abstract}
The taxonomic positions of five enteroadherent bacterial pig isolates, showing phenotypic characteristics most similar to those of Enterococcus durans and Enterococcus hirae, were investigated in a polyphasic study that included 165 rDNA sequence analysis, DNA-DNA hybridizations, DNA base-ratio determinations, whole-cell protein fingerprinting, D11344-primed PCR typing and an extensive examination of phenotypic properties. The results demonstrated that the organisms represent a new species in the Enterococcus faecium species group, for which the name Enterococcus villorum sp. nov. is proposed. The type strain is LMG $12287^{\top}$ ( = CCM $\left.4887^{\top}\right)$.
\end{abstract}

Keywords: Enterococcus villorum sp. nov., identification, polyphasic taxonomy, adhesion, pig

\section{INTRODUCTION}

The enterococci belong phylogenetically to the clostridial subdivision of the Gram-positive bacteria. They form a distinct cluster, with Vagococcus, Tetragenococcus and Carnobacterium as their closest neighbours (Collins et al., 1989; Aguirre \& Collins, 1992; Devriese et al., 1993, Devriese \& Pot, 1995; Franz et al., 1999). The phenotypic description of the genus Enterococcus is vague, as there are no characters that distinguish them unequivocally from other Grampositive, catalase-negative, coccus-shaped bacteria (Devriese et al., 1993; Devriese \& Pot, 1995). Currently, almost 20 species are assigned to the genus, which is subdivided in at least four species groups based on 16S rRNA gene sequence similarity (Williams et al., 1991; Devriese \& Pot, 1995; Teixeira et al., 1996; Stiles \& Holzapfel, 1997; De Vaux et al., 1998).

The Enterococcus faecium species group currently contains four species: E. faecium, Enterococcus durans, Enterococcus hirae and Enterococcus mundtii. The history of the species E. faecium, E. durans and E. hirae

\footnotetext{
†Present address: Laboratory of Microbiology, AZ St.-Jan AV, Brugge, Belgium.

$\ddagger$ Present address: Yakult Belgium sa/nv, Brussels, Belgium.

The EMBL accession number for the 16S rDNA sequence of Enterococcus villorum LMG $12287^{\top}$ is AJ271329.
}

cannot be considered separately. When first described, the species E. faecium and E. durans were classified in the genus Streptococcus (Orla-Jensen, 1919; Sherman \& Wing, 1937). In 1970, Kalina proposed to transfer [Streptococcus] faecium to the genus Enterococcus and to reclassify [Streptococcus] durans as E. faecium subsp. durans. Both propositions of Kalina (1970) were not generally accepted, although several other authors confirmed that, on the basis of phenotypic similarity, $[S$.] faecium and [S.] durans represent a single taxon (Deibel \& Seeley, 1974; Jones, 1978). Only after extended nucleic acid studies was the genus Enterococcus officially recognized and it initially comprised two species, the type species Enterococcus faecalis and E. faecium (Schleifer \& Kilpper-Bälz, 1984). Shortly afterwards, $[S$.] durans was reclassified in the genus Enterococcus as E. durans, based on its low DNADNA homology with E. faecium and few phenotypic differences (Collins et al., 1984). One year later, it was demonstrated that strains with biochemical properties intermediate between those of E. faecium and E. durans constituted a separate genomic species and these were named E. hirae (Farrow \& Collins, 1985). The most recently described member of the E. faecium species group is E. mundtii, containing yellow-pigmented nonmotile strains (Collins et al., 1986).

Members of the E. faecium species group showing typical adhesion to the apical surface of the enterocytes 
of the small intestine of animals have been described since the mid 1980s. They have been implicated as possible causes of diarrhoea in the young of different mammal host species (see Discussion). Such strains often remained unidentified or were classified as $E$. durans or E. hirae.

In the present paper, a polyphasic study was performed on a collection of five isolates, all originating from pigs. Two were originally identified as $E$. durans from cases of diarrhoea in piglets in Canada and Korea. A third strain was isolated in the USA from the jejunum of a nursery pig. Preliminary analyses of these three isolates revealed high phenotypic similarity to two pig isolates received from R. R. Facklam (Centers for Disease Control and Prevention, Atlanta, GA, USA); all five isolates were tentatively classified as E. hiraelike.

A polyphasic taxonomic study indicated that the five pig isolates could not be assigned to a known Enterococcus species, but constituted a separate but homogeneous taxon. All data demonstrated that they represented a new species, for which the name Enterococcus villorum sp. nov. is proposed.

\section{METHODS}

Bacterial strains and growth conditions. The sources of the isolates and reference strains studied are listed in Table 1. All strains were grown and maintained on MRS agar (Oxoid) and incubated aerobically at $37^{\circ} \mathrm{C}$, unless indicated otherwise. Bacteriological purity was checked by plating and examining living and Gram-stained cells.
PAGE of whole-cell proteins. After incubation of cells for $24 \mathrm{~h}$, whole-cell protein extracts were prepared and SDSPAGE was performed as described by Pot et al. (1994). Densitometric analysis, normalization and interpolation of the protein profiles and numerical analysis were performed by using the GELCOMPAR software package, versions 3.1 and 4.0 (Applied Maths).

D11344-primed PCR analysis. DNA was prepared following the method described by Pitcher et al. (1989). PCR amplification using the oligonucleotide D11344 as primer and subsequent electrophoresis were performed as described previously (Descheemaeker et al., 1997). Conversion, normalization and numerical analysis of the fingerprints were performed by using the GELCOMPAR software package.

16S rDNA sequence analysis. Genomic DNA of E. villorum LMG $12287^{\mathrm{T}}$ was extracted by using the Puregene DNA isolation kit (Gentra Systems) according to the protocol supplied by the manufacturer with the following modification: proteinase $\mathrm{K}\left(200 \mu \mathrm{g} \mathrm{ml}^{-\mathbf{1}}\right.$; Merck) was added during lysis of the cells. A fragment of the $16 \mathrm{~S}$ rDNA gene (corresponding to positions 10-1541 in the Escherichia coli numbering system) was amplified by PCR using the conserved primers MH1 (5'-AGTTTGATCCTGGCTCAG-3') and $\mathrm{pH}$ (5'-AAGGAGGTGATCCAGCCGCA-3'). The PCR product was purified using a Qiaquick PCR purification kit (Qiagen), according to the manufacturer's instructions. Sequencing was performed using an Applied Biosystems 377 DNA Sequencer and the protocols of the manufacturer (Perkin-Elmer) with the ABI Prism Dye Terminator Cycle Sequencing Ready Reaction kit. The eight sequencing primers used are listed in Coenye et al. (1999). Sequence assembly was performed by using the program AUTOASSEMBLER (Perkin-Elmer).

Phylogenetic analysis was performed using the software

\section{Table 1 Strains studied}

Culture collections are abbreviated as: ATCC, American Type Culture Collection, Manassas, VA, USA; CCM, Czech Collection of Microorganisms, Brno, Czech Republic; CDC, Centers for Disease Control or Communicable Disease Center, US Public Health Service, Atlanta, GA, USA; LMG, BCCM/LMG Culture Collection Laboratorium voor Microbiologie, University of Gent, Gent, Belgium; NCFB, National Collection of Food Bacteria, Agricultural and Food Research Council Institute of Food Research, Aberdeen, UK.

\begin{tabular}{|c|c|c|c|}
\hline Taxon & Strain & Other strain designations & Source and place of isolation \\
\hline Enterococcus avium & LMG $10744^{\mathrm{T}}$ & ATCC $14025^{\mathrm{T}}$ & Human, faeces \\
\hline Enterococcus durans & LMG $10746^{\mathrm{T}}$ & ATCC $19432^{\mathrm{T}}$ & Dried milk \\
\hline Enterococcus durans & LMG 12283 & SP 2 & Chicken, intestine; Belgium \\
\hline Enterococcus durans & LMG 12903 & NCFB 498 & Cheddar cheese \\
\hline Enterococcus durans & LMG 14202 & $\mathrm{GBg} 22$ & Herring, meat; Belgium \\
\hline Enterococcus faecium & LMG $11423^{\mathrm{T}}$ & NCFB $942^{\mathrm{T}}$ & \\
\hline Enterococcus gallinarum & LMG $13129^{\mathrm{T}}$ & ATCC $49573^{\mathrm{T}}$ & Chicken, intestine \\
\hline Enterococcus hirae & LMG $6399^{\mathrm{T}}$ & ATCC $8043^{\mathrm{T}}$ & \\
\hline Enterococcus hirae & LMG 11425 & NCFB 1648 & \\
\hline Enterococcus hirae & LMG 11492 & NCFB 2683 & Chicken, crop \\
\hline Enterococcus hirae & LMG 14489 & $94 / 290$ & Parrot, spleen; Belgium \\
\hline Enterococcus mundtii & LMG $10748^{\mathrm{T}}$ & ATCC $43186^{\mathrm{T}}$ & Soil \\
\hline Enterococcus villorum & LMG $12287^{\mathrm{T}}$ & $88-5474^{\mathrm{T}}, \mathrm{CCM} 4887^{\mathrm{T}}$ & Pig, intestine; Canada \\
\hline Enterococcus villorum & LMG 16296 & CDC 1391-83 & Pig; USA \\
\hline Enterococcus villorum & LMG 17496 & St-Paul 4204 & Pig, intestine; USA \\
\hline Enterococcus villorum & LMG 19177 & CDC 1390-83 & Pig; USA \\
\hline Enterococcus villorum & LMG 19179 & Strain SNUVP & Pig, intestine; Korea \\
\hline
\end{tabular}




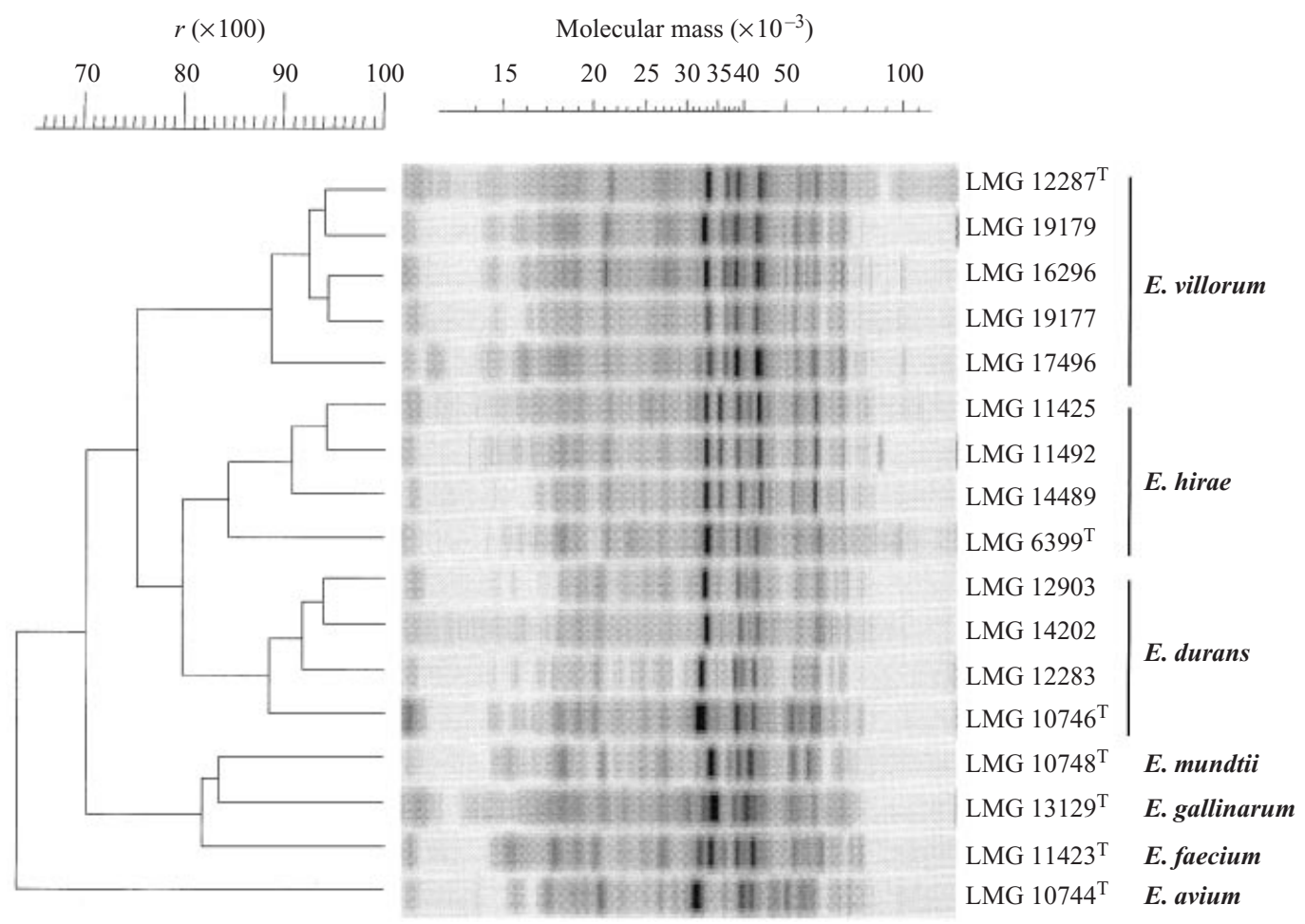

Fig. 1. Protein profiles of Enterococcus strains and the corresponding dendrogram derived from the unweighted pair group average linkage of correlation coefficients $r$ (expressed for convenience as percentages).

package GENECOMPAR (Applied Maths) after including the consensus sequence in an alignment of small ribosomal subunit sequences collected from the international nucleotide sequence library EMBL. This alignment was calculated pairwise using an open gap penalty of $100 \%$ and a unit gap penalty of $0 \%$. A similarity matrix was created by homology calculation with a gap penalty of $0 \%$; unknown bases were discarded. The resulting tree was constructed using the neighbour-joining method.

DNA base compositions. Cells were cultivated in MRS broth (Oxoid) for $24 \mathrm{~h}$ at $37^{\circ} \mathrm{C}$. DNA was extracted from $2.5 \mathrm{~g}$ wet weight of cells using the protocol described by Marmur (1961) with the following modifications: (i) $1 \mathrm{~h}$ before harvesting, penicillin $\mathrm{G}$ (Sigma) was added to a final concentration of $250 \mathrm{mg} \mathrm{l}^{-1}$; (ii) cells suspended in Tris $/ \mathrm{HCl}$ buffer were treated with lysozyme $\left(8 \mathrm{mg} \mathrm{ml}^{-1}\right)$ overnight before addition of SDS; and (iii) lysed cells were treated with proteinase $\mathrm{K}$ (360 $\mathrm{mg} \mathrm{^{-1 }}$; Merck) for $2 \mathrm{~h}$ at $37^{\circ} \mathrm{C}$. For determination of the DNA base composition, DNA was enzymically degraded into nucleosides as described by Mesbah et al. (1989). The nucleoside mixture obtained was then separated by HPLC using a Waters Symmetry Shield $\mathrm{C} 8$ column thermostatted at $37^{\circ} \mathrm{C}$. The solvent was $0.02 \mathrm{M}$ $\left(\mathrm{NH}_{4}\right) \mathrm{H}_{2} \mathrm{PO}_{4}(\mathrm{pH} 4 \cdot 0)$ with $1.5 \%$ acetonitrile. Non-methylated lambda phage DNA (Sigma) was used as the calibration reference.

DNA-DNA hybridization experiments. High-molecular-mass native DNA was prepared as described above for determination of the DNA base composition. DNA-DNA hybridizations were performed using a modification of the microplate method described by Ezaki et al. (1989), using a HTS7000 Bio Assay Reader (Perkin-Elmer) for the fluorescence measurements. Biotinylated DNA was hybridized with single-stranded unlabelled DNA, noncovalently bound to microplate wells. Hybridizations were performed at $34^{\circ} \mathrm{C}$ in hybridization mixture $(2 \times \mathrm{SSC}$, $5 \times$ Denhardt's solution, $2.5 \%$ dextran sulfate, $50 \%$ formamide, $100 \mu \mathrm{g}$ denatured salmon sperm DNA ml ${ }^{-1}, 1250 \mathrm{ng}$ biotinylated probe DNA ml-1).

Phenotypic analyses. Growth tests and biochemical activities were carried out as described by Devriese et al. (1997). The galleries API 20 STREP, API $50 \mathrm{CH}$ and rapid ID32 STREP (bioMérieux) were used and the BBL CRYSTAL Gram-positive kit (Becton Dickinson) was used as an additional test system. Susceptibility to antibiotics was evaluated on Isosensitest medium (Oxoid) using Sensitab tablets (Rosco). Tests were carried out and interpreted according to the instructions of the manufacturers.

\section{RESULTS}

\section{PAGE of whole-cell proteins}

Duplicate protein extracts were prepared to check the reproducibility of the growth conditions and the preparation of the extracts. The correlation coefficient between duplicate protein patterns was $r \geqslant 0.95$.

The whole-cell protein profiles of the E. villorum strains were initially compared with patterns of more than 600 enterococcal strains, representing all currently described Enterococcus species, and formed a separate cluster (Pot \& Janssens, 1993; data not shown). In Fig. 1 , a dendrogram is shown that was obtained after 


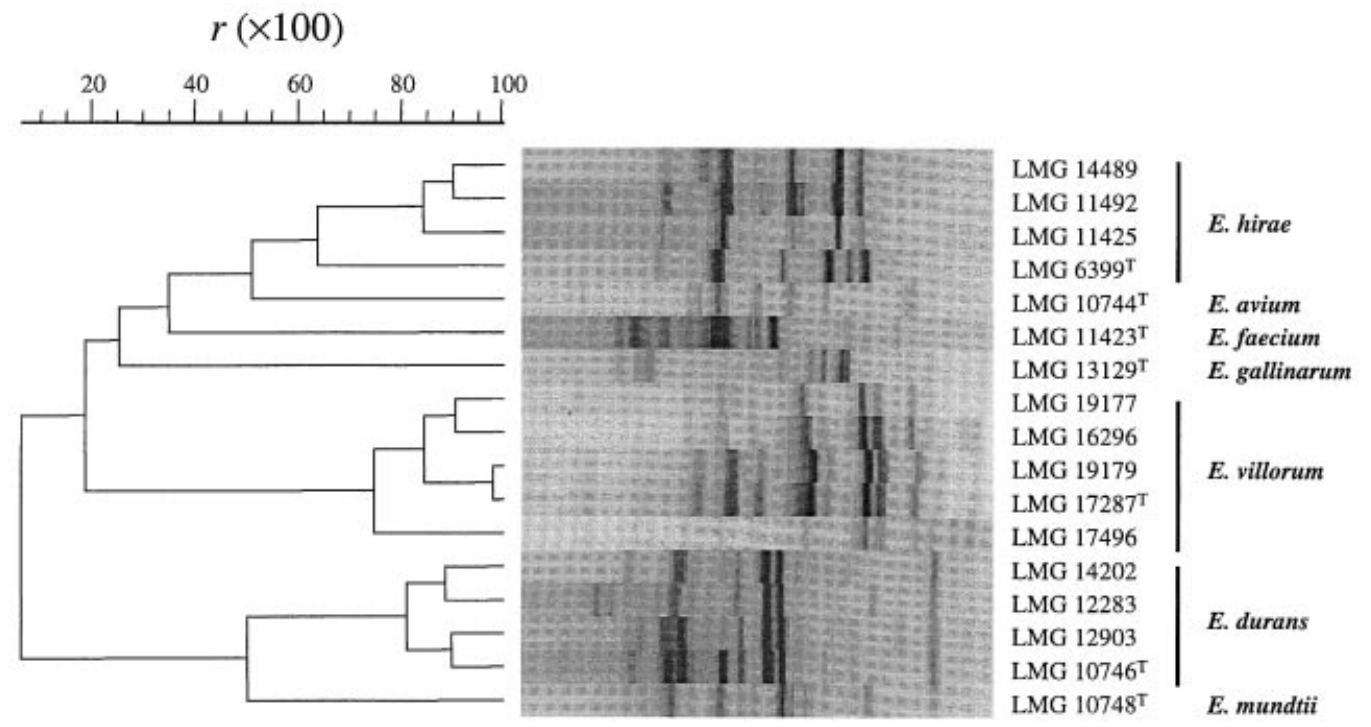

Fig. 2. D11344-primed $P C R$ patterns of Enterococcus strains and the corresponding dendrogram derived from the unweighted pair group average linkage of correlation coefficients $r$ (expressed for convenience as percentages).

average-linkage cluster analysis of E. villorum strains and reference strains of E. durans, E. hirae and other members of the E. faecium species group. For comparison, we also included the type strain of Enterococcus avium, a member of the E. avium species group, and Enterococcus gallinarum, a member of the $E$. gallinarum species group. The E. villorum strains grouped in a single cluster at a level of $r \geqslant 0.89$, clearly separated from clusters containing strains of $E$. durans $(r \geqslant 0.88)$ and $E$. hirae $(r \geqslant 0.84)$. Other reference strains constituted distinct branches at a level of $r \leqslant 0 \cdot 83$.

Visual inspection of the electrophoregrams (Fig. 1) revealed almost identical electrophoretic patterns within each cluster.

\section{D11344-primed PCR analysis}

The $r$ value for reproducibility of the PCR assay and the running conditions, as estimated by the analysis of duplicate DNA extracts of several strains, was higher than 0.92 .

Numerical analysis of the DNA band patterns is presented in Fig. 2 and showed that E. villorum strains formed a single cluster, well separated from the speciesspecific clusters obtained for the reference taxa.

Visual comparison of the band patterns (Fig. 2) within each of the clusters revealed only minor differences between most strains.

\section{$16 \mathrm{~S}$ rDNA sequence analysis}

The 16S rDNA gene of E. villorum LMG $12287^{\mathrm{T}}$ showed highest similarities to sequences of reference strains of the E. faecium species group (99.1-98.8\%). Somewhat lower values were observed to members of

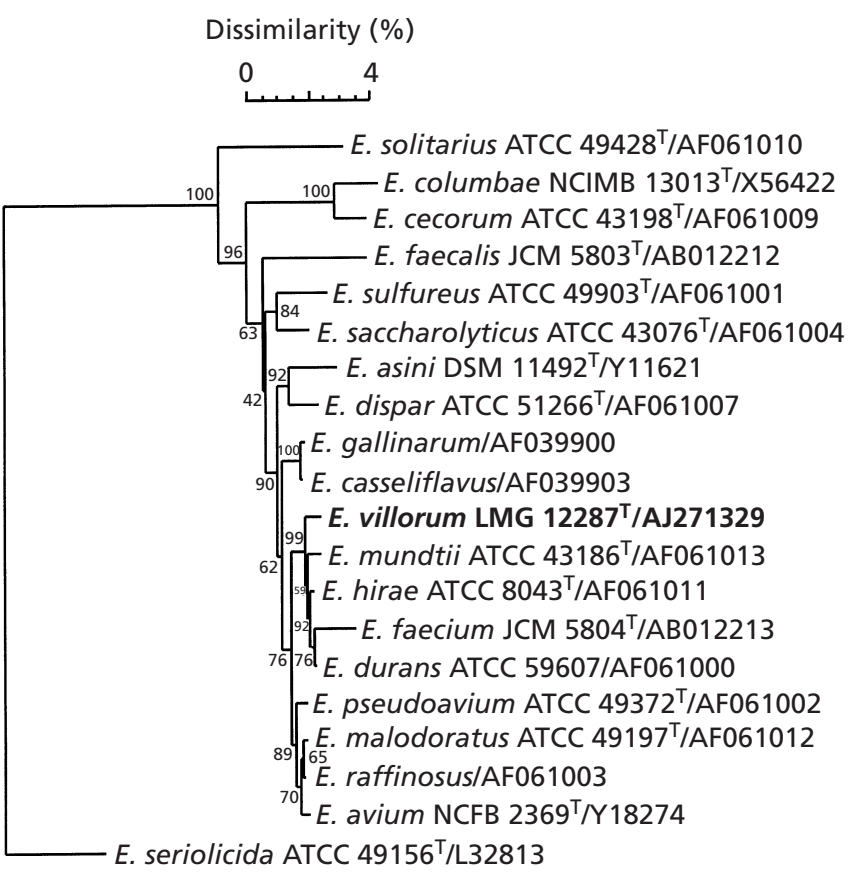

Fig. 3. Distance matrix tree showing the phylogenetic relationships of Enterococcus species based on 16S rDNA sequence comparisons. Enterococcus seriolicida was used as the outgroup and bootstrap probability values are indicated at the branch-points (100 trees resampled). Accession numbers are given, together with strain designations where known.

the E. avium species group $(98 \cdot 4-98 \cdot 1 \%)$, the $E$. gallinarum species group (98.0-97.8\%), Enterococcus dispar $(97.6 \%)$ and Enterococcus saccharolyticus $(97.5 \%)$. Values lower than $97 \%$ were found with other described species. A phylogenetic tree is presented in Fig. 3. 
Table 2 Percentage DNA-DNA binding values of E. villorum strains and related Enterococcus species

\begin{tabular}{|c|c|c|c|c|c|c|c|c|}
\hline Source of DNA & 1 & 2 & 3 & 4 & 5 & 6 & 7 & 8 \\
\hline 1. E. villorum $\mathrm{LMG} 12287^{\mathrm{T}}$ & 100 & & & & & & & \\
\hline 2. E. villorum LMG 17496 & 99 & 100 & & & & & & \\
\hline 3. E. durans LMG $10746^{\mathrm{T}}$ & 31 & 27 & 100 & & & & & \\
\hline 4. E. faecium $\mathrm{LMG} 11423^{\mathrm{T}}$ & 27 & 28 & 36 & 100 & & & & \\
\hline 5. E. hirae LMG $6399^{\mathrm{T}}$ & 37 & 38 & 26 & 30 & 100 & & & \\
\hline 6. E. mundtii $\mathrm{LMG} 10748^{\mathrm{T}}$ & 29 & 31 & 20 & 29 & 27 & 100 & & \\
\hline 7. E. avium LMG $10744^{\mathrm{T}}$ & 14 & 14 & 12 & 13 & 12 & 11 & 100 & \\
\hline 8. E. gallinarum LMG $13129^{\mathrm{T}}$ & 15 & 17 & 16 & 14 & 14 & 14 & 13 & 100 \\
\hline
\end{tabular}

Table 3 Characteristics that differentiate $E$. villorum from members of the $E$. faecium species group

Data for taxa other than E. villorum were obtained from Devriese \& Pot (1995) and Knight \& Shlaes (1986). Characters are scored as: + , positive; D, strain-dependent; $\mathrm{D}+$, usually positive; $\mathrm{D}-$, usually negative; - , negative. ND, Not determined.

\begin{tabular}{|c|c|c|c|c|c|}
\hline Characteristic & E. villorum & E. hirae & E. durans & E. faecium & E. mundtii \\
\hline Yellow pigmentation & - & - & - & - & + \\
\hline Clotting of skimmed milk & - & - & $\mathrm{D}+$ & $\mathrm{D}$ & ND \\
\hline$\beta$-Mannosidase & - & $\mathrm{D}+$ & $\mathrm{D}+$ & $\mathrm{D}+$ & ND \\
\hline Susceptibility to tobramycin & + & - & + & ND & ND \\
\hline \multicolumn{6}{|l|}{ Production of acid from: } \\
\hline L-Arabinose & - & - & - & + & + \\
\hline Mannitol & - & - & - & $\mathrm{D}+$ & + \\
\hline Methyl $\beta$-D-glucopyranoside* & - & + & + & ND & ND \\
\hline Raffinose & - & $\mathrm{D}-$ & $\mathrm{D}-$ & $-\dagger$ & $\mathrm{D}+$ \\
\hline Sucrose & - & + & $\mathrm{D}$ & $\mathrm{D}+$ & + \\
\hline D-Xylose & $\mathrm{D}+$ & - & - & $\mathrm{D}-$ & + \\
\hline
\end{tabular}

* Used at $0.05 \%$ instead of the usual $1 \%$ in phenol red broth.

$\dagger$ E. faecium strains from poultry are usually positive for production of acid from raffinose.

\section{DNA base composition}

The DNA G + C content of strains LMG $12287^{\mathrm{T}}$ and LMG 17496 was $35 \cdot 3$ and $35 \cdot 1 \mathrm{~mol} \%$, respectively.

\section{DNA-DNA hybridization experiments}

Results are summarized in Table 2. The level of DNA-DNA binding between E. villorum strains LMG $12287^{\mathrm{T}}$ and LMG 17496 was $99 \%$. Homology levels of $27-38 \%$ were observed between E. villorum strains and members of the E. faecium species group. The highest binding values were found with $E$. hirae (37-38\%). Significantly lower values were observed with members of the E. avium and E. gallinarum species groups $(14-17 \%)$.

\section{Phenotypic analyses}

Colonies were enterococcal-like and they showed alpha haemolysis on blood agar. The strains were not motile and produced uniform turbidity in broth cultures. They grew on azide-containing enterococcal selective media, but colonies developed more slowly than is commonly seen with related enterococci of the E. faecium species group. The strains grew in $6.5 \%$ $\mathrm{NaCl}$ broth and caused blackening of bile/aesculin agar.

From a large set of phenotypic tests, only three differentiated all E. villorum strains from their closest taxonomic neighbour, E. hirae: inability to produce acid from methyl $\beta$-D-glucopyranoside and sucrose and susceptibility to tobramycin. Characteristics that differentiate $E$. villorum from other taxa of the $E$. faecium species group are shown in Table 3. A detailed phenotypic description of E. villorum is given below.

\section{DISCUSSION}

A polyphasic taxonomic study was performed to clarify the taxonomic position of five E. hirae-like isolates. The results of the present study allowed us to assign all five strains to a new species, for which we propose the name E. villorum sp. nov. 


\section{Taxonomic position of $E$. villorum}

Comparison of the 16S rDNA sequence of strain LMG $12287^{\mathrm{T}}$ with those of other species of the genus Enterococcus (Fig. 3) indicated that the closest relatives are members of the E. faecium species group (99.1$98 \cdot 8 \%$ ) and confirmed the high phenotypic similarity to the species $E$. durans and E. hirae. DNA-DNA hybridizations were performed between E. villorum LMG $12287^{\mathrm{T}}$ and LMG 17496 and the type strains of all members of the E. faecium species group (Table 2). For comparison, the type strains of $E$. avium and $E$. gallinarum were also included. Among the E. villorum strains, DNA-binding values of $99 \%$ were observed. No significant DNA relatedness was measured between strains of the latter taxon and the type strains of other Enterococcus species. It should be noted, however, that considerably higher binding values were observed with members of the E. faecium species group $(27-38 \%)$ than with representative strains of the $E$. avium species group $(14 \%)$ and E. gallinarum species group (15-17\%). A highest binding value of 37-38\% with $E$. hirae confirmed the high phenotypic relatedness to the latter taxon.

\section{Differentiation of E. villorum from other Enterococcus species}

Both whole-cell protein electrophoresis and D11344primed PCR analysis indicate that E. villorum strains form a homogeneous group that can be differentiated easily from other Enterococcus species (Figs 1 and 2). Both methodologies have been described for specieslevel differentiation of enterococci (Descheemaeker et al., 1997).

Using biochemical tests (Table 3), E. villorum can be differentiated from $E$. hirae and $E$. durans by its inability to acidify methyl $\beta$-D-glucopyranoside and by the ability of most strains to produce acid from Dxylose. Except for its sensitivity to tobramycin and lack of activity on sucrose, no other features tested allowed the differentiation of the new taxon from $E$. hirae. Differentiation from $E$. durans is even more difficult. Clotting of skimmed milk and $\beta$-mannosidase are useful additional tests, but they are not really discriminative. Like E. durans, E. villorum is susceptible to tobramycin (Knight \& Shlaes, 1986). Other characteristics useful in the differentiation of $E$. villorum from members of the E. faecium species group are presented in Table 3.

\section{Source of isolation and pathogenicity}

The E. villorum strains were all isolated from pigs and originate from three different countries: Canada (LMG 12287 ${ }^{\mathrm{T}}$ ), Korea (LMG 19179) and United States (LMG 16296, LMG 17496 and LMG 19177). Two of them (LMG $12287^{\mathrm{T}}$ and LMG 19179) were associated with neonatal diarrhoea in piglets (Drolet et al., 1990; Cheon \& Chae, 1996); mortality was negligible. In both cases, the most consistent and predominant histological feature was the extensive colonization of the mucosal surface of the small intestine. Colonization extended from the tips to the bases of the villi. In both cases, the pathogenesis of diarrhoea remained unknown and was not associated with enterotoxin production or substantial mucosal injury. It was suggested that a decreased activity of brush border digestive enzymes such as lactase and alkaline phosphatase interferes with digestion and absorption of the brush border (Drolet et al., 1990; Cheon \& Chae, 1996). A third strain, LMG 17496, was isolated in the Minnesota Veterinary Diagnostic Laboratory of the University of Minnesota at St Paul (MN, USA) from a nursery pig with a jejunum that was colonized with Gram-positive cocci (C. Lindeman, personal communication). Two other porcine isolates, for which no detailed information on origin was provided, were obtained from the CDC (LMG 16296 and LMG 19177).

Enterococci that show typical adhesion to the apical surface of the enterocytes of the small intestine of animals have been described as possible causes of diarrhoea in the young of different mammal host species: foals (Tzipori et al., 1984), infant rats (Etheridge et al., 1988; Etheridge \& Vonderfecht, 1992; Hoover et al., 1985), piglets before weaning (Drolet et al., 1990; Cheon \& Chae, 1996), calves (Rogers et al., 1992) and dog pups (Collins et al., 1988). One report concerned a similar condition in adult dogs (Jergens et al., 1991) and another in an adult cat (Hélie \& Higgins, 1999). In most of these studies, the enteropathogen was presumptively identified as E. durans (Tzipori et al., 1984; Drolet et al., 1990; Cheon \& Chae, 1996; Rogers et al., 1992; Collins et al., 1988). According to Devriese \& Pot (1995), however, E. durans is found in domestic animals mainly in the intestines of some preruminant calves (Devriese et al., 1992) and in young chicks (Devriese et al., 1991), and no reports are available on the pathogenicity of the species. Several animal pathogenic strains, originally identified as $E$. durans, were reclassified as E. hirae (Devriese \& Haesebrouck, 1991). E. hirae is found in the gut of all important domestic animal species (Devriese et al., 1987).

Whether or not the enteroadherent enterococci reported in these animal hosts belong to E. villorum remains to be determined. The characteristics that have been reported for the rat strains differ from those of E. villorum. The strains from calves and dogs have not been characterized in detail in the literature and were not available for study.

\section{Description of Enterococcus villorum sp. nov.}

Enterococcus villorum (vil.lo'rum. L. n. villus rough hair, anatomical term for flocculate structures in the small intestine; gen. pl. villorum).

Strains are Gram-positive, non-sporulating and nonmotile cocci. Colonies grow on azide-containing enterococcal selective media, on bile/aesculin agar and 
in $6.5 \% \mathrm{NaCl}$ broth. Colonies on Slanetz-Bartley medium are pink and develop slowly. All strains are alpha-haemolytic.

All strains react positively in the following tests: Voges-Proskauer, $\beta$-glucosidase, pyrrolidonylarylamidase, leucine arylamidase, arginine dihydrolase, glycyltryptophan arylamidase, hydrolysis of aesculin, 4 -methylumbelliferyl (MU) $\beta$-D-glucoside, 4-MU $N$ acetyl $\beta$-D-glucosaminide, L-phenylalanine 7-amido-4methyl-coumarin (AMC), L-pyroglutamic acid AMC, L-tryptophan AMC, $p$-nitrophenyl $\beta$-D-glucoside, $p$ nitrophenyl $\beta$-D-cellobioside, $o$-nitrophenyl $\beta$-Dgalactoside and $p$-nitrophenyl $\alpha$-D-galactoside. All strains produce acid from amygdalin, arbutin, cellobiose, glycerol (weak and only visible after $2 \mathrm{~d}$ ), Dglucose, $N$-acetylglucosamine, D-fructose, galactose, $\beta$-gentiobiose, lactose, maltose, D-mannose, melibiose, ribose, salicin and trehalose. All strains are negative in the amylase plate test, in tests for catalase, hippurate hydrolysis, alkaline phosphatase, $\beta$-glucuronidase, $\beta$ mannosidase, alanine-phenylalanine-proline arylamidase, hydrolysis of L-valine AMC, 4-MU $\alpha$-Dglucoside, L-arginine AMC, 4-MU phosphate, 4-MU $\beta$-D-glucuronide, L-isoleucine AMC, $p$-nitrophenyl phosphate, proline- and leucine- $p$-nitroanilide, urease and acid production from adonitol, D- and L- arabitol, D- and L-arabinose, D-cyclodextrin, 2- and 5-ketogluconate, dulcitol, erythritol, D- and L-fucose, $\alpha$ methyl D-glucoside, methyl $\beta$-D-glucopyranoside, gluconate, glycogen, inositol, inulin, D-lyxose, maltotriose, mannitol, $\alpha$-methyl D-mannoside, melezitose, pullulan, raffinose, rhamnose, sorbitol, L-sorbose, sucrose, D-tagatose, xylitol, L-xylose and $\beta$-methyl Dxyloside. Four strains produce acid from D-xylose and three strains react positively in the $p$-nitrophenyl $\alpha$-Dmaltoside test. These tests were the only variable reactions noted. All strains are susceptible to the aminoglycoside antibiotic tobramycin.

The organisms examined were isolated from pigs and originate from three different countries. Adhesion to enterocytes is a prominent characteristic of at least three of the strains studied. The type strain is LMG $12287^{\mathrm{T}}$, which was isolated from the gut of a piglet in Canada and was associated with neonatal diarrhoea. The DNA $G+C$ content is $35 \cdot 1-35 \cdot 3 \mathrm{~mol} \%$.

All strains have been deposited in the BCCM/LMG Bacteria Collection (Laboratorium voor Microbiologie Gent, Gent, Belgium) and the type strain has been deposited in the Czech Collection of Microorganisms (Masaryk University, Brno, Czech Republic).

\section{ACKNOWLEDGEMENTS}

This work was supported by the European Communities project 'Enterococci in food fermentations. Functional and safety aspects' (FAIR programme FAIR-CT97-3078). This research was also supported by the Prime Minister's Services - Federal Office for Scientific, Technical and Cultural Affairs, Belgium. We thank D.-S. Cheon, R. R. Facklam,
R. Higgins and C. Lindeman for providing of the strains studied. We thank B. Hoste and K. Vandemeulebroecke for performing the $16 \mathrm{~S}$ rDNA sequence analysis and J. Goris for determination of the DNA base compositions.

\section{REFERENCES}

Aguirre, M. \& Collins, M. D. (1992). Phylogenetic analysis of Alloiococcus otitis gen. nov., sp. nov., an organism from human middle ear fluid. Int $J$ Syst Bacteriol 42, 79-83.

Cheon, D.-S. \& Chae, C. (1996). Outbreak of diarrhea associated with Enterococcus durans in piglets. J Vet Diagn Invest 8, 123-124.

Coenye, T., Falsen, E., Vancanneyt, M., Hoste, B., Govan, J. R. W., Kersters, K. \& Vandamme, P. (1999). Classification of Alcaligenes faecalis-like isolates from the environment and human clinical samples as Ralstonia gilardii sp. nov. Int J Syst Bacteriol 49, 405-413.

Collins, M. D., Jones, D., Farrow, J. A. E., Kilpper-Bälz, R. \& Schleifer, K. H. (1984). Enterococcus avium nom. rev., comb. nov.; E. casseliflavus nom. rev., comb. nov.; E. durans nom. rev., comb. nov.; E. gallinarum comb. nov.; and E. malodoratus sp. nov. Int J Syst Bacteriol 34, 220-223.

Collins, M. D., Farrow, J. A. E. \& Jones, D. (1986). Enterococcus mundtii sp. nov. Int J Syst Bacteriol 36, 8-12.

Collins, J. E., Bergeland, M. E., Lindeman, C. J. \& Duimstra, J. R. (1988). Enterococcus (Streptococcus) durans adherence in the small intestine of a diarrheic pup. Vet Pathol 25, 396-398.

Collins, M. D., Ash, C., Farrow, J. A. E., Wallbanks, S. \& Williams, A. M. (1989). $16 \mathrm{~S}$ ribosomal ribonucleic acid sequence analyses of lactococci and related taxa. Description of Vagococcus fluvialis gen. nov., sp. nov. J Appl Bacteriol 67, 453-460.

Deibel, R. H. \& Seeley, H. W., Jr (1974). Family II. Streptococcaceae fam. nov. In Bergey's Manual of Determinative Bacteriology, 8th edn, pp. 490-517. Edited by R. E. Buchanan \& N. E. Gibbons. Baltimore: Williams \& Wilkins.

Descheemaeker, P., Lammens, C., Pot, B., Vandamme, P. \& Goossens, H. (1997). Evaluation of arbitrarily primed PCR analysis and pulsed-field gel electrophoresis of large genomic DNA fragments for identification of enterococci important in human medicine. Int J Syst Bacteriol 47, 555-561.

De Vaux, A., Laguerre, G., Diviès, C. \& Prévost, H. (1998). Enterococcus asini sp. nov. isolated from the caecum of donkeys (Equus asinus). Int J Syst Bacteriol 48, 383-387.

Devriese, L. A. \& Haesebrouck, F. (1991). Enterococcus hirae in different animal species. Vet Rec 129, 391-392.

Devriese, L. A. \& Pot, B. (1995). The genus Enterococcus. In The Genera of Lactic Acid Bacteria, pp. 327-367. Edited by B. J. B. Wood \& W. H. Holzapfel. London: Blackie Academic \& Professional.

Devriese, L. A., Van de Kerckhove, A., Kilpper-Bälz, R. \& Schleifer, K. H. (1987). Characterization and identification of Enterococcus species isolated from the intestines of animals. Int $J$ Syst Bacteriol 37, 257-259.

Devriese, L. A., Hommez, J., Wijfels, R. \& Haesebrouck, F. (1991). Composition of the enterococcal and streptococcal intestinal flora of poultry. J Appl Bacteriol 71, 46-50.

Devriese, L. A., Laurier, L., De Herdt, P. \& Haesebrouck, F. (1992). Enterococcal and streptococcal species isolated from faeces of calves, young cattle and dairy cows. J Appl Bacteriol 72, 29-31.

Devriese, L. A., Pot, B. \& Collins, M. D. (1993). Phenotypic identification of the genus Enterococcus and differentiation of 
phylogenetically distinct enterococcal species and species groups. J Appl Bacteriol 75, 399-408.

Devriese, L. A., Pot, B., Vandamme, P., Kersters, K., Collins, M. D., Alvarez, N., Haesebrouck, F. \& Hommez, J. (1997). Streptococcus hyovaginalis sp. nov. and Streptococcus thoraltensis sp. nov., from the genital tract of sows. Int J Syst Bacteriol 47, 1073-1077.

Drolet, R., Higgins, R. \& Jacques, M. (1990). L'entéropathie associée à Enterococcus (Streptococcus) durans chez le porcelet. Méd Vét Quebec 20, 114-116.

Etheridge, M. E. \& Vonderfecht, S. L. (1992). Diarrhea caused by a slow-growing Enterococcus-like agent in neonatal rats. Lab Anim Sci 42, 548-550.

Etheridge, M. E., Yolken, R. H. \& Vonderfecht, S. L. (1988). Enterococcus hirae implicated as a cause of diarrhea in suckling rats. J Clin Microbiol 26, 1741-1744.

Ezaki, T., Hashimoto, Y. \& Yabuuchi, E. (1989). Fluorometric deoxyribonucleic acid-deoxyribonucleic acid hybridization in microdilution wells as an alternative to membrane filter hybridization in which radioisotopes are used to determine genetic relatedness among bacterial strains. Int $J$ Syst Bacteriol 39, 224-229.

Farrow, J. A. E. \& Collins, M. D. (1985). Enterococcus hirae, a new species that includes amino acid assay strain NCDO 1258 and strains causing growth depression in young chickens. Int $J$ Syst Bacteriol 35, 73-75.

Franz, C. M. A. P., Holzapfel, W. H. \& Stiles, M. E. (1999). Enterococci at the crossroads of food safety? Int $J$ Food Microbiol 47, 1-24.

Hélie, P. \& Higgins, R. (1999). Diarrhea associated with Enterococcus faecium in an adult cat. J Vet Diagn Invest 11, 457-458.

Hoover, D., Bendele, S. A., Wightman, S. R., Thompson, C. Z. \& Hoyt, J. A. (1985). Streptococcal enteropathy in infant rats. Lab Anim Sci 35, 635-641.

Jergens, A. E., Moore, F. M., Prueter, J. C. \& Yankauskas, P. J. (1991). Adherent gram-positive cocci on the intestinal villi of two dogs with gastrointestinal disease. $\mathrm{J} \mathrm{Am} \mathrm{Vet} \mathrm{Med} \mathrm{Assoc}$ 198, 1950-1952.

Jones, D. (1978). Composition and differentiation of the genus Enterococcus. In Streptococci, pp. 1-49. Edited by F. A. Skinner \& L. B. Quesnel. London: Academic Press.

Kalina, A. P. (1970). The taxonomy and nomenclature of enterococci. Int J Syst Bacteriol 20, 185-189.

Knight, R. G. \& Shlaes, D. M. (1986). Deoxyribonucleic acid relatedness of Enterococcus hirae and 'Streptococcus durans' homology group II. Int J Syst Bacteriol 36, 111-113.
Marmur, J. (1961). A procedure for the isolation of deoxyribonucleic acid from microorganisms. J Mol Biol 3, 208-218.

Mesbah, M., Premachandran, U. \& Whitman, W. B. (1989). Precise measurement of the $\mathrm{G}+\mathrm{C}$ content of deoxyribonucleic acid by high-performance liquid chromatography. Int J Syst Bacteriol 39, 159-167.

Orla-Jensen, S. (1919). The lactic acid bacteria. Mem R Acad Sci Denmark Sect Sci Ser 8 5, 81-197.

Pitcher, D. G., Saunders, N. A. \& Owen, R. J. (1989). Rapid extraction of bacterial genomic DNA with guanidinium thiocyanate. Lett Appl Microbiol 8, 151-156.

Pot, B. \& Janssens, D. (1993). The potential role of a culture collection for identification and maintenance of lactic acid bacteria. In The Lactic Acid Bacteria. Proceedings of the First Lactic Acid Computer Conference, pp. 81-87. Wymondham, UK: Horizon Scientific Press.

Pot, B., Vandamme, P. \& Kersters, K. (1994). Analysis of electrophoretic whole-organism protein fingerprints. In Chemical Methods in Prokaryotic Systematics, pp. 493-521. Edited by M. Goodfellow \& A. G. O'Donnell. Chichester: Wiley.

Rogers, D. C., Zeman, D. H. \& Erickson, E. D. (1992). Diarrhea associated with Enterococcus durans in calves. J Vet Diagn Invest 4, 471-472.

Schleifer, K. H. \& Kilpper-Bälz, R. (1984). Transfer of Streptococcus faecalis and Streptococcus faecium to the genus Enterococcus nom. rev. as Enterococcus faecalis comb. nov. and Enterococcus faecium comb. nov. Int J Syst Bacteriol 34, 31-34.

Sherman, J. M. \& Wing, H. U. (1937). Streptococcus durans n. sp. J Dairy Sci 20, 165-167.

Stiles, M. E. \& Holzapfel, W. H. (1997). Lactic acid bacteria of foods and their current taxonomy. Int J Food Microbiol 36, 1-29.

Teixeira, L. M., Merquior, V. L. C., Vianni, M. da C. E., Carvalho, M. da G. S., Fracalanzza, S. E. L., Steigerwalt, A. G., Brenner, D. J. \& Facklam, R. R. (1996). Phenotypic and genotypic characterization of atypical Lactococcus garvieae strains isolated from water buffalos with subclinical mastitis and confirmation of $L$. garvieae as a senior subjective synonym of Enterococcus seriolicida. Int J Syst Bacteriol 46, 664-668.

Tzipori, S., Hayes, J., Sims, L. \& Withers, M. (1984). Streptococcus durans: an unexpected enteropathogen of foals. J Infect Dis 150, 589-593.

Williams, A. M., Rodrigues, U. M. \& Collins, M. D. (1991). Intrageneric relationships of enterococci as determined by reverse transcriptase sequencing of small-subunit rRNA. Res Microbiol 142, 67-74. 